\title{
IMPACTS OF WATER EXTRACT OF DIESEL OIL AND GASOLINE FUELS ON GROWTH AND SOME BIOCHEMICAL ACTIVITIES OF DUNALIELLA SALINA TEOD.
}

\author{
Eman M. Fakhry and Mohamed S. M. Abdel-Kareem \\ Botany Department, Faculty of Science, Alexandria University, Egypt
}

\begin{abstract}
Two-way ANOVA proved that different concentrations of water extract of diesel and gasoline fuels significantly $(\mathrm{p} \leq 0.01)$ affect the growth and biochemical activities of Dunaliella salina. The effects were found to depend mainly on type, concentration of the extract and period of culturing. Low concentration of both extracts $(25 \%)$ ameliorated the growth and most of the measured biochemical analyses (pigment fractions, carbohydrates and protein). On the contrary, concentrations higher than $25 \%$ decreased these measured parameters. The toxic effect of these extracts was increased by increasing their concentration. The results proved also that gasoline is more toxic to $D$. salina than diesel fuel oil.
\end{abstract}

Key words: Diesel oil fuel, gasoline fuel, growth, metabolic activity, protein patterns, Dunaliella salina.

\section{Introduction}

Oil fractions are among the commonest and most obvious pollutants of marine and estuarine waters (Nunes and Benville, 1979). A significant increase in the world consumption of oil was usually accompanied by growing incidences of pollution. When, crude oil or its fractions are present on water bodies some of their constituents especially hydrocarbons may dissolve in water. These dissolved constituents at high concentrations may become toxic to the coastal biota (Newaey and Seed, 1995).

Also, when oil is spilt in water, it forms a scum over the surface of water and acts as a barrier for exchange of gases (Nelson-Smith, 1970). Most attention has been paid to the effect of oil fractions on growth (Chen et al., 1992) and photosynthesis (Singh and Gaur, 1990; Jankevicius et al., 1992). At the same time, little attention has been paid on the biochemical behavior of algae. Jordon et $a l$. (2002) found that algae treated by diesel fuel showed significant changes in the polar lipids and in the saturation of fatty acids. Also, Zachleder and Tukaj (1993) found that by increasing the concentration of oil, dispersant or a mixture of both the inhibitory effect on growth and macromolecules synthesis in Scenedesmus sp. was expressed earlier. The presence of crude oil or its refinery products in the culture media of algae markedly influenced their growth, protein 
and nucleic acids content. The toxic effect was found to be dependent on concentration of the extract (El-Sheekh et al., 2000).

Diesel oil and gasoline fuels are among the commonest oil fractions usually used as energy source for tanks and ships. It is well known fact that ships are the only means for transportation of crude oil and its fractions. This may play a role in sea water pollution which in turn will affect the biota of sea water. These two fuels have been shown to have toxic effects on microorganisms, including algae (Dennington et al., 1975; Batterton et al., 1978; Karydis, 1979; McKanight et al., 1983; Hegseth and Ostgaard, 1985; Harrison et al., 1986; Herman et al., 1990 and Piehler et al., 1997).

Studies on the effects of oil pollution on metabolic activities of microalgae (the primary producers of the seas) are of primary concern since they are the most basic and essential components of aquatic food chain. Without these microalgae the ocean would subsequently be unable to sustain its other life forms (Sheppard and Price, 1991). At the same time, such studies are required to understand the relationship between their biology and pollution (Piehler et al., 2003).

This study attempts to assess the impact of different concentrations of the aqueous extracts of diesel oil and gasoline fuels on growth and some biochemical activities of the marine alga Dunaliella salina, usually used in aquacultures.

\section{Material and Methods \\ Biological material}

Axenic culture of Dunaliella salina was obtained from the algal collection of Phycology laboratory, Faculty of Science, Alexandria University, Egypt.

\section{Culture conditions and pollutants treatments}

Sterile cultures were set up in three replicates for each growth condition in both control (MH medium according to Leoblich, 1982 at $\mathrm{pH} 7.5$ ) and treated cultures. Inoculates of known equal cell number were always taken from exponentially growing stock cultures and pipetted under sterile conditions into sterilized 500-ml Erlenmeyer flasks containing $150 \mathrm{ml}$ media and plugged with cotton plugs. Cultures were grown at controlled conditions of light (3500 lux) and temperature $\left(25 \pm 5^{\circ} \mathrm{C}\right)$ in a controlled culture room. Light regime was $12 \mathrm{~h}$ : $12 \mathrm{~h}$ light-dark. The culture flasks were manually shaken several times daily.

For the preparation of the aqueous extracts of diesel and gasoline, the method developed by Boylan and Tripp (1971) was used. Two sets, each of 1000 $\mathrm{ml}$, MH media were shaken overnight with $50 \mathrm{ml}$ diesel and gasoline fuels separately. Recovering of the aqueous extract in each set takes place using separating funnel. This aqueous extract was referred to as $100 \%$. Appropriate dilutions from this aqueous extract were made, using $\mathrm{MH}$ medium, so that the 
polluted media were obtained with fuel concentrations of $25 \%, 50 \%, 75 \%$ and $100 \%$. However, in case of gasoline extract, only three concentrations were tested since the organism died at concentration $100 \%$ gasoline extract.

Growth measurement and biochemical analysis

Growth (number of cells/ml culture) was estimated using a hemacytometer slide $(0.1 \mathrm{~mm}$ deep). At least four replicates were taken in each determination. Chlorophyll "a" and "b" contents were determined spectrophotometrically according to Jeffery and Humphery (1975). $\beta$-carotene content was estimated according to the equation proposed by Jaspers (1965). Total carbohydrates content by the method described by Dubois et al. (1959) and glycerol by the method of Chitlaru and Pick (1989).

Electrophoretic analysis of soluble protein

Discontinuous disc-gel electrophoresis technique was applied according to Scandalios (1969). Gels containing soluble protein bands were stained with $0.04 \%$ PAGE-blue G-90 dye in $3.0 \%$ perchloric acid. However, the similarity matrices between different protein patterns were obtained using the similarity coefficient of Czekanowski (1913).

\section{Statistical analysis}

Data concerning the effect of water extracts of diesel oil and gasoline fuels on growth and some biochemical parameters of $D$. salina were subjected to the standard Two-way analysis of variance (ANOVA) using the COSTAT 2.0 statistical analysis soft ware manufactured by COMOIT soft ware company (1986).

\section{Results and Discussion}

Growth of Dunaliella salina:

The variation in growth (cell number) of Dunaliella salina cultured in MH medium (control) as well as in different concentrations of polluted media was highly significant $(\mathrm{p} \leq 001)$ as evaluated by Two-way ANOVA (Figure 1 . In control as well as in diesel polluted media, the organism entered the exponential phase (which extends for 12 days in approximately all treatments) after a short lag phase.

Growth of Dunaliella salina in $25 \%$ diesel water extract enhanced till nearly the $10^{\text {th }}$ day of culturing then reduced compared to control. On the contrary, the other concentrations of diesel extract gradually reduced the growth of Dunaliella salina till the end of the experiment compared to control. In case of gasoline polluted medium, the organism in all concentrations used passed a lag phase which lasted for 2 days. However, the growth of the organism increased gradually after this lag phase till the $10^{\text {th }}$ day, but still less than control. The rate of growth differed according to the concentration tested. It is worth to mention that at concentration $25 \%$ the rate of growth after the $10^{\text {th }}$ day surpassed that of control till the end of the experiment. 
(A) Diesel oil fuel

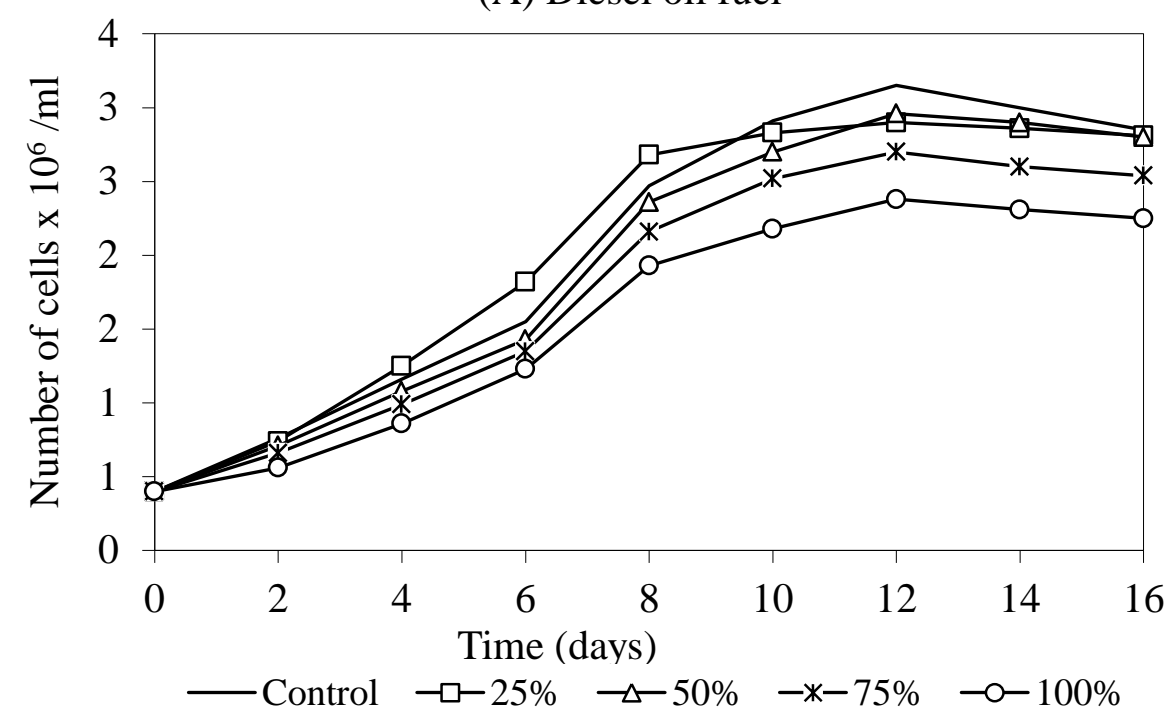

(B) Gasoline fuel

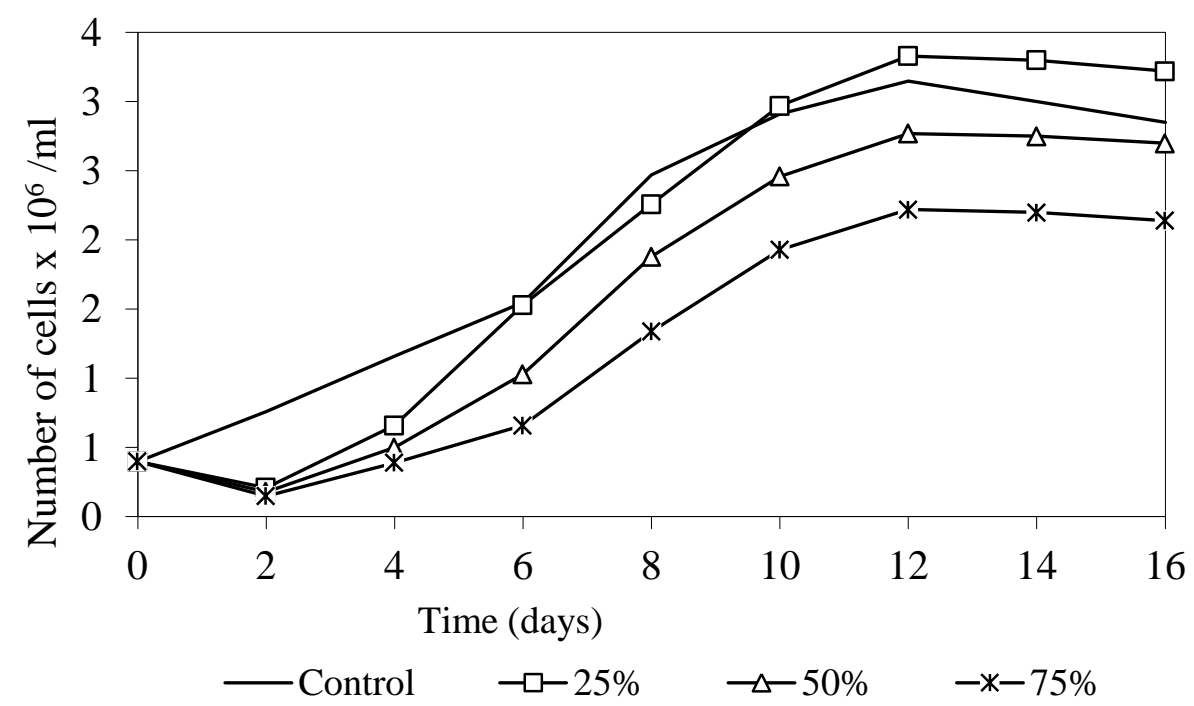

Figure (1): Growth of Dunaliella salina (measured by cell number) under different concentrations of water extracts of diesel (A) and gasoline (B) fuels

(The effect of time, concentration and interaction of both on cell number were highly significant ( $p \leq 0.01)$ as evaluated by Two-way ANOVA) 
Many workers showed that all plants, including algae, when exposed to environmental stress display reduced growth (Chapin, 1991; Cowan et al., 1992; Abdel-Kareem, 1999; Allam and Abdel-Kareem, 2001 and Yang et al., 2002). Meanwhile, oil pollution, including diesel and gasoline, reduces the growth of many algal species, for example, Chlorella pyrenoidosa (Coffey et al., 1977), Skletonema costatum (Karydis, 1981), Tetraselmis suecica (Fabregas et al., 1984), Scenedesmus quadricauda (Dennington et al., 1975 and Kentzer and Tukaj, 1985), Isochrysis sp. (Ansari et al., 1997), two species of Chlorella, C. homospora and C. vulgaris (El-Sheekh et al., 2000), Scenedesmus obliquus (Lu et al., 2001) and Nannochloropsis salina (Mohammady et al., 2005).

Baker (1970) reported that oils vary in their toxicity according to the content of low-boiling compounds, unsaturated compounds, aromatics and acids. The higher concentration of these constituents, the more the toxicity of the oil. At the same time, the low boiling hydrocarbons are most toxic to plants and algal species. Thus, the higher toxicity of gasoline than diesel could be due to its lower boiling range. The toxicity effect of diesel and gasoline, which leads to growth reduction, may be attributed to the cell membrane damage (Kauss and Huntchinson, 1978), inhibition of enzyme system, photosynthesis, respiration, protein and nucleic acid synthesis (Ikawa et al., 1992) and/or the inhibition of cell division (Piehler et al., 2003).

Stimulatory effect of low concentrations of diesel and gasoline on Dunaliella salina growth may be due to the presence of some growth regulating compounds and/or trace elements (Hunfford, 1971). The ability of this alga to utilize fuel as a source of organic carbon and/or the uptake and metabolization of fuel constituents were documented by O'Brien and Dixon (1976), Zawadzki and Langowska (1982); Sikkema et al. (1995). At the same time, stimulation of algal growth at low oil concentration, including diesel and gasoline, has been accertained by many authors (e. g. Gordon and Prouse, 1973; Dunstan et al., 1975; Karydis, 1979 and Chan and Chiu, 1985).

Effect of fuel pollutants on pigment content:

a- Chlorophylls

A significant $(\mathrm{p} \leq 0.05)$ decrease in chlorophylls a and b production by $D$. salina was noticed at approximately all gasoline concentrations after 4, 8 and 12 days compared to control (Figure 2). Except for concentration $25 \%$ where at 8 days the content of chlorophyll a and b were higher than control. On the contrary, except for $100 \%$, all diesel concentrations enhanced nearly chlorophyll a \& b production during the exponential phase of growth (4 and 8 days). Long incubation periods (12 days) in all diesel concentrations reduced chlorophyll "a" $\&$ "b" production. These results go in harmony with those obtained by Gordon and Prouse (1973), Atlas et al. (1976), Bott et al. (1979), Chan and Chiu (1985) and Tukaj (1987). 


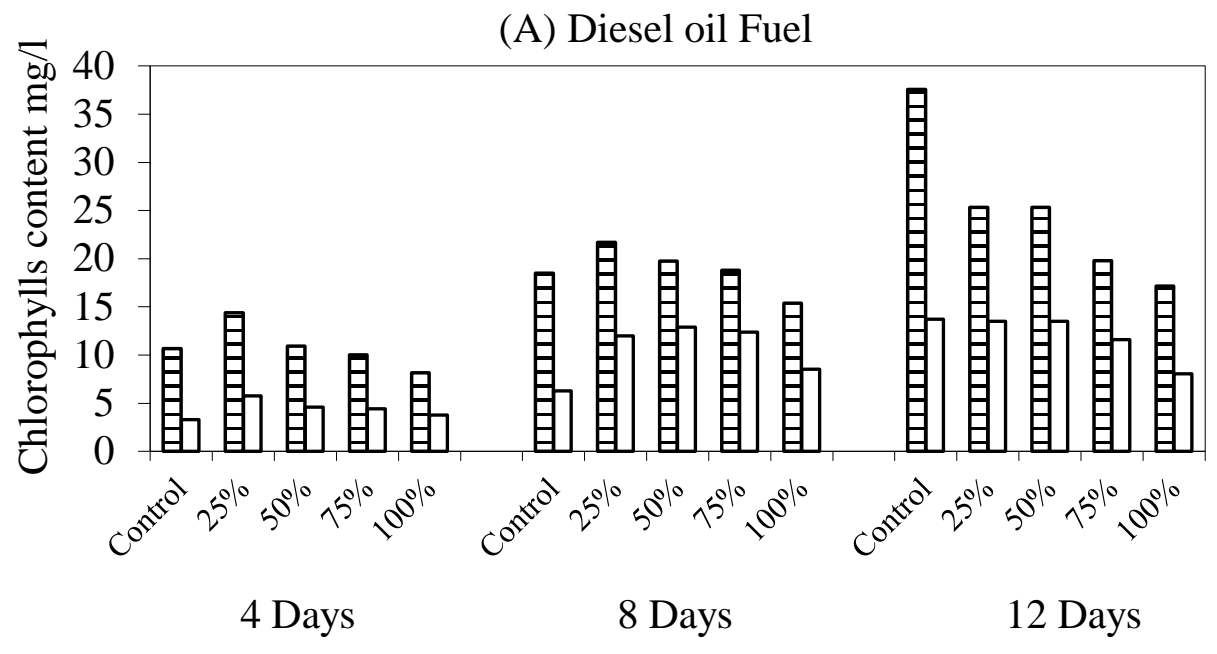

(B) Gasoline fuel

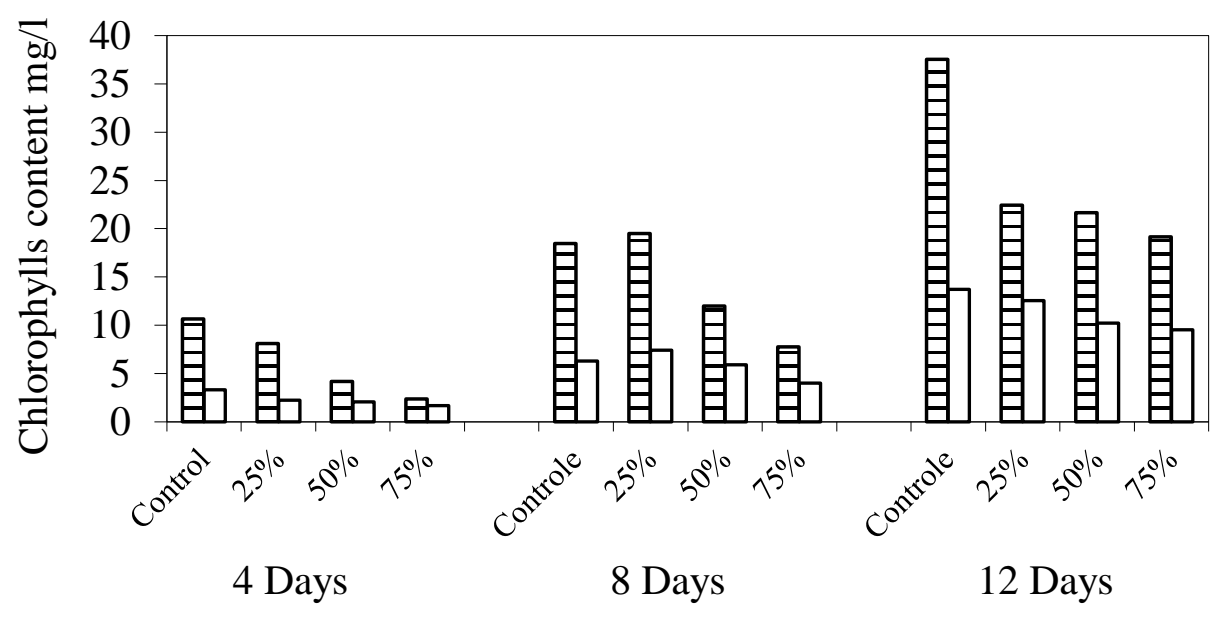

$\boxminus$ Chlorophyll a $\square$ Chlorophyll b

Figure (2) Effect of water extracts of diesel (A) and gasoline (B) fuels on chlorophylls content of Dunaliella salina after 4, 8 and 12 days of culturing

(The effect of fuel concentrations on the chlorophylls content were significant ( $p \leq$ 0.05) as evaluated by Two-way ANOVA) 
The inhibitory effect of fuel oil pollution on pigment content was suggested to be due to the degradation and bleaching of pigments (Zachleder and Tukaj, 1993). At the same time, low boiling point hydrocarbons lead to membrane damage (Kauss and Hutchinson, 1978) and increase membrane permeability (Sikkema et al., 1995), which may reduce the proton motive force in the cell. If so, the electrochemical gradient across the thylakoid membrane will be compromised and, in turn, the photosynthetic yield of the two systems (I\&II) will decrease (Piehler et al., 2003).

b- $\beta$-carotene

Figure 3 illustrates the effect of the aqueous extract of diesel and gasoline on $\beta$-carotene content in Dunaliella salina. It is clear that, after 4 and 8 days of culturing, approximately all concentrations of diesel significantly $(p \leq 0.05)$ ameliorated the production of $\beta$-carotene. However, after 12 days culturing, it increased only under low diesel concentration $(25 \%)$. On the contrary, gasoline extract showed a reverse effect, where, most of its concentrations significantly reduced $\beta$-carotene production after 4,8 and 12 days. The exceptions are $25 \%$ and $50 \%$ after 8 days. These results may be interpreted to the fact that Dunaliella salina could utilize diesel fuel rather than gasoline fuel as organic carbon source in the biosynthesis of $\beta$-carotene, a result also coincides with that obtained by Wang et al. (2002).

\section{Effect of fuel pollutants on carbohydrate and glycerol contents:}

Reduction of soluble and insoluble carbohydrates in response to all concentrations of aqueous extracts of both diesel and gasoline was significant ( $\mathrm{p} \leq$ 0.05 ) as evaluated by Two-way ANOVA test (Figure 4). Similarly, the increase of glycerol content in response to all diesel concentrations and some of gasoline concentrations was noticed (Figure 5). Since it has been shown that glycerol is a photosynthetic product of Dunaliella (Craigie and McLachlan, 1964; Wegman, 1969 and 1971), thus glycerol may be suggested as a photosynthetic indicator rather than soluble and insoluble carbohydrates in Dunaliella salina.

The effect of aqueous extracts of diesel and gasoline on Dunaliella salina may be accompanied by osmotic disturbance, which, in turn, was adjusted by glycerol production. Meanwhile, most of the intracellular osmotic pressure in Dunaliella is provided by glycerol (Ben-Amotz and Avron, 1983). However, the reduction of various carbohydrate fractions in response to high concentrations of oils could be due to the inhibitory effect of oils upon the photosynthetic activity and the utilization of carbohydrates as substrates in increased nitrogen metabolism (Chan and Chiu, 1985).

\section{Effect of fuel pollutants on protein pattern of Dunaliella salina:}

Plate (I) illustrates the protein patterns of Dunaliella salina grown under controlled as well as polluted media. The number of bands decreased in all treated cells than that of untreated cells (control). There are 5 marker bands in control, not appeared in the other treated cells. 


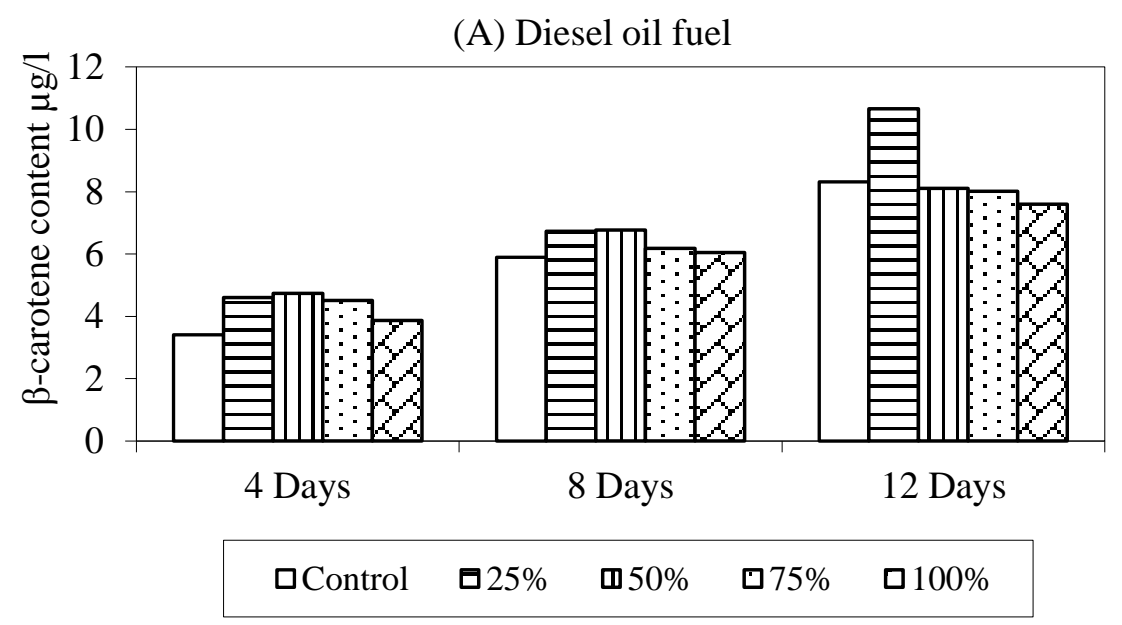

(B) Gasoline fuel

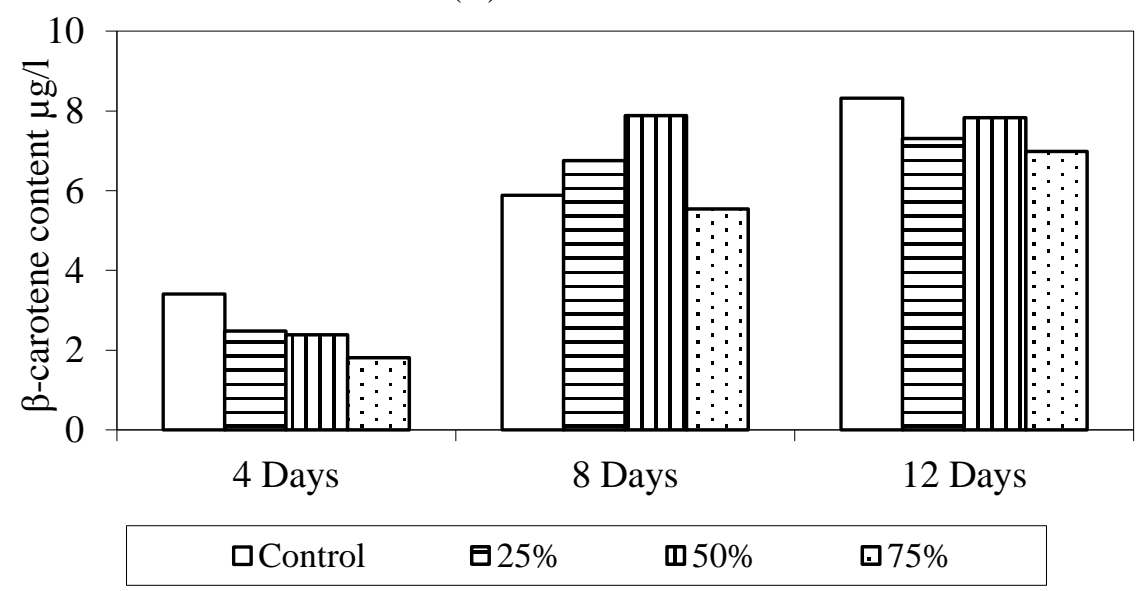

Figure (3): Effect of water extracts of diesel (A) and gasoline (B) fuels on $\beta$-carotene content of Dunaliella salina after 4,8 and 12 days of culturing.

(The effect of fuel concentrations on $\beta$-carotene content were significant $(p \leq 0.05)$ as evaluated by Two-way ANOVA) 

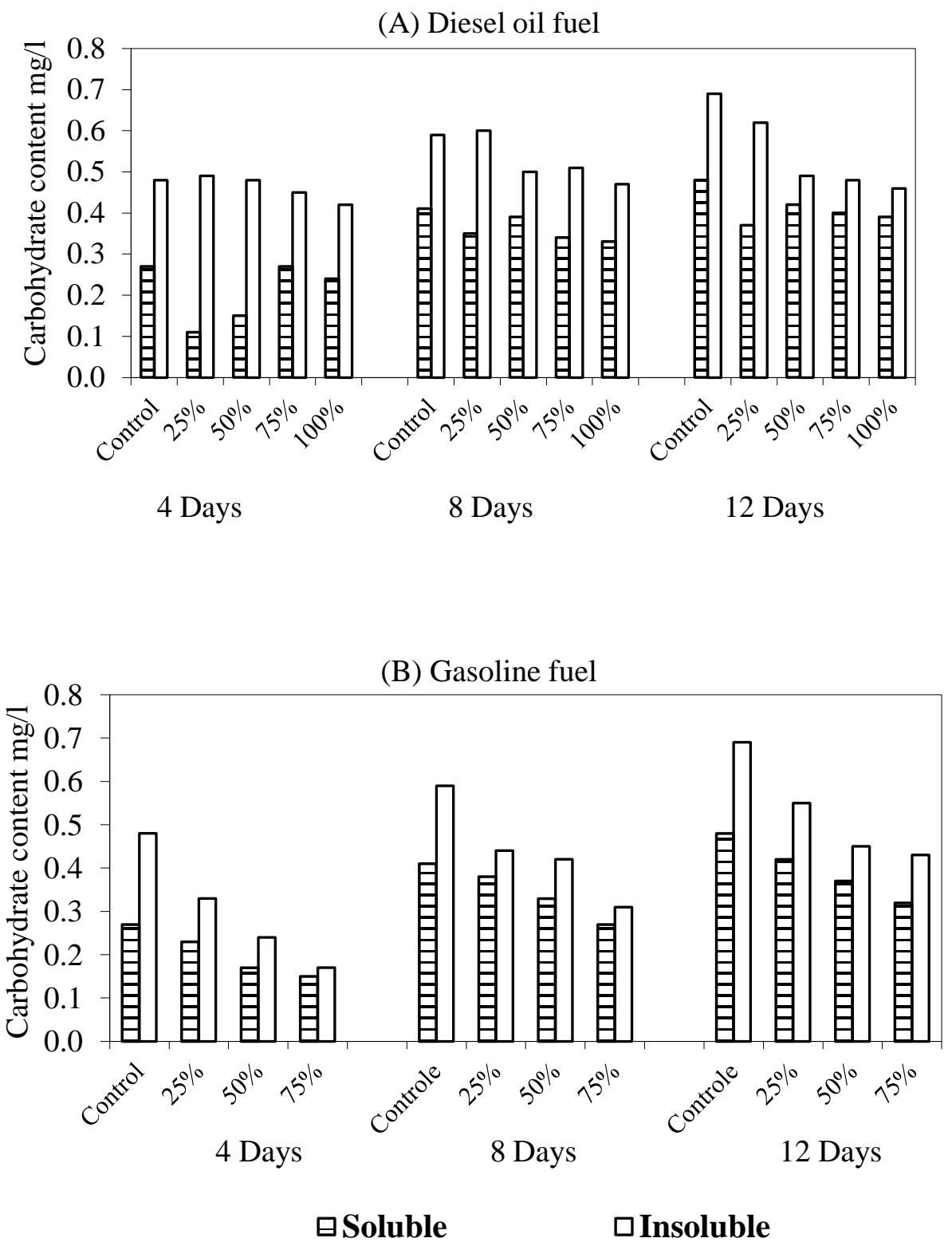

Figure (4): Effect of water extracts of diesel (A) and gasoline (B) fuels on carbohydrate content of Dunaliella salina after 4, 8 and 12 days of culturing (The effect of fuel concentrations on the insoluble carbohydrates content were significant $(p \leq 0.05)$ as evaluated by Two-way ANOVA) 
(A) Diesel oil fuel

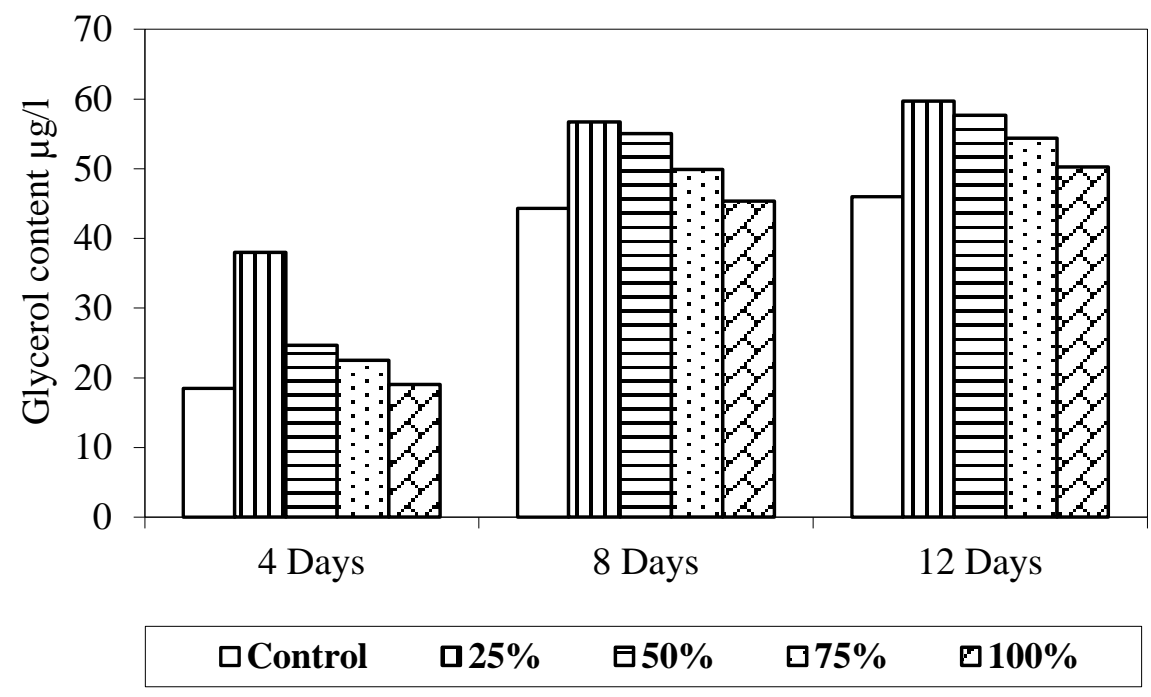

(B) Gasoline fuel

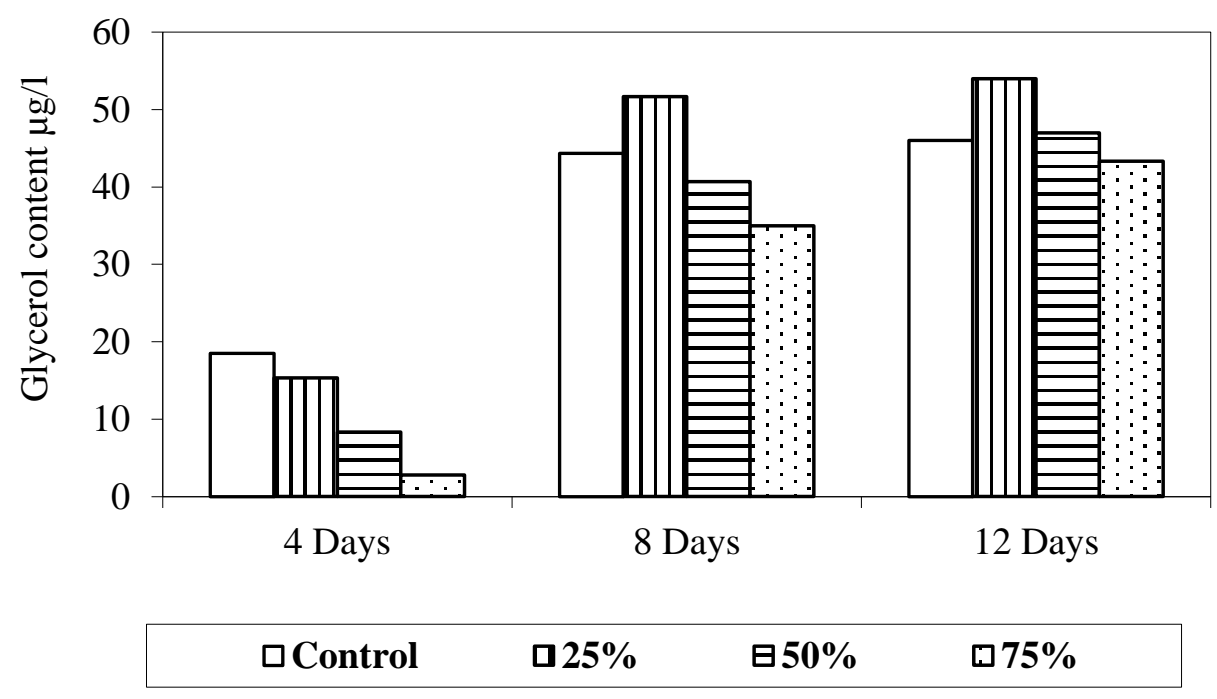

Figure (5): Effect of water extracts of diesel (A) and gasoline (B) fuels on glycerol content of Dunaliella salina after 4,8 and 12 days of culturing

(The effect of fuel concentrations on glycerol content were significant $(p \leq 0.05)$ as evaluated by Two-way ANOVA) 


\section{Plate I}

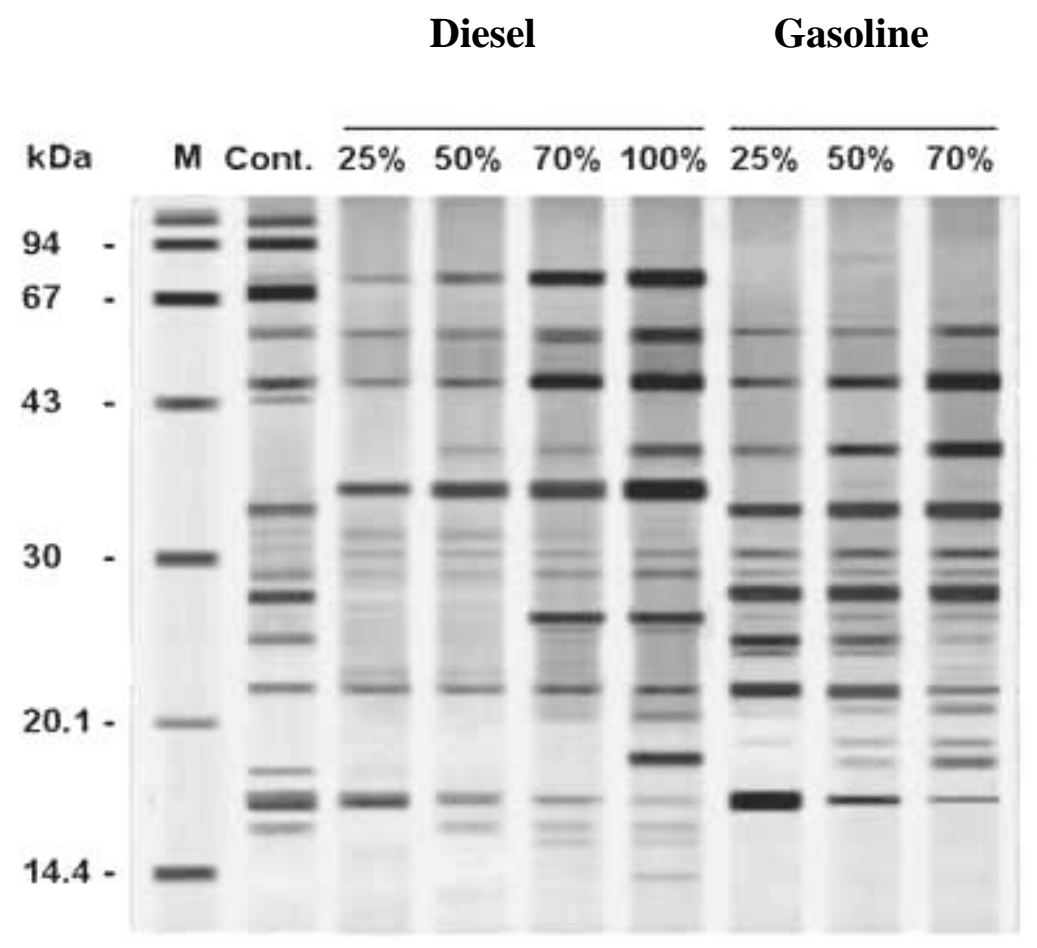

\section{Protein patterns of Dunaliella salina grown in different concentrations of diesel and gasoline fuels.}

Of these 5 bands, 4 have high molecular weight (43, 67, 94 and about $100 \mathrm{k} \mathrm{Da}$ respectively), and the $5^{\text {th. }}$ band has low molecular weight $(17 \mathrm{k} \mathrm{Da})$.

Similarity matrices based on the protein patterns of control and treated cells were presented in Table (1). The similarity between control and treated cells decreased by the increase of pollutant's concentration. Meanwhile, there are great similarities between protein profiles of cells treated with different concentrations of the same pollutant, diesel or gasoline. These similarities were directly proportional to the fuel's concentration, i. e. the more the close concentrations, the more similarity degrees.

These results were not surprising, since pollution by oil inhibits the biosynthesis of ribonucleic acids and modifies the polymerization of DNA, as reported by Davavin et al. (1975) after their work on Ulva lactuca and Egyptian J. of Phycol. Vol. 7(1), 2006 -27 - 
Polysiphonia opaca. They also reported that labile DNA (a fraction of DNA which is characterized by metabolic activity which determines the synthesis of specific proteins), rather than stable DNA, is more sensitive to oil pollution and this may result in the destruction of the mechanism of the expression of heredity. At the same time, oil compounds reduces the number of DNA replication rounds and inhibition of DNA synthesis was accompanied by slightly delayed cessation of RNA and protein synthesis (Zachleder and Tukaj, 1993).

Table (1): Similarity matrices based on protein patterns of Dunaliella salina grown in control and different concentrations of diesel and gasoline aqueous extracts.

\begin{tabular}{|c|c|c|c|c|c|c|c|c|}
\hline & $\begin{array}{l}\bar{o} \\
\bar{\Xi} \\
\bar{\partial}\end{array}$ & 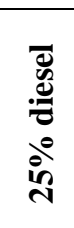 & 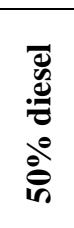 & 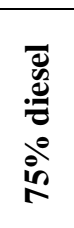 & 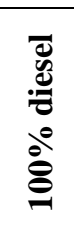 & 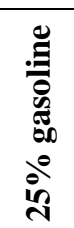 & 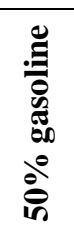 & 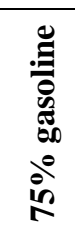 \\
\hline Control & 1.00 & & & & & & & \\
\hline $25 \%$ diesel & 0.59 & 1.00 & & & & & & \\
\hline $50 \%$ diesel & 0.57 & 0.95 & 1.00 & & & & & \\
\hline $75 \%$ diesel & 0.47 & 0.82 & 0.88 & 1.00 & & & & \\
\hline $100 \%$ diesel & 0.44 & 064 & 0.79 & 0.79 & 1.00 & & & \\
\hline $25 \%$ gasoline & 0.60 & 0.43 & 0.58 & 0.54 & 0.50 & 1.00 & & \\
\hline $50 \%$ gasoline & 0.44 & 0.40 & 0.54 & 0.64 & 0.60 & 0.93 & 1.00 & \\
\hline $75 \%$ gasoline & 0.39 & 0.50 & 0.56 & 0.59 & 0.62 & 0.96 & 0.97 & 1.00 \\
\hline
\end{tabular}

Finally, the results revealed that growth and metabolic activities of Dunaliella salina were affected by toxicity of the water soluble fractions of diesel and gasoline extracts. The degree of toxicity depended mainly on type of extract, concentration of the extract, length of culture period and perhaps type of alga used.

\section{References}

Abdel-Kareem, M. S. M. (1999). Influence of ultraviolet radiation on growth, photosynthetic pigments and protein profile of Dunaliella salina Teod. (Chlorophceae). Egypt. J. Bot., 1:77-95.

Allam, M. M. and Abdel-Kareem, M. S. (2001). Effect of sewage and industrial wastewater on growth, photosynthetic pigments and ultrastructure of Dunaliella salina Teod. (Chlorophyceae). El-Minia Science Bulletin, 13(2): 209-227.

Ansari, Z.; Saldanha, M. and Rajkumar, R. (1997). Effect of petroleum hydrocarbons on the growth of microalga Isicrysis sp. (Chrysophyta). Indian J. Mar. Sci., 26:372-376. 
Atlas, M.; Edmund, A.; Frank, A. and Roy, E. (1976). Effects of petroleum pollutants on arctic microbial pollution. Environ. Pollut., 10:35-39.

Baker, J. M. (1970). The effect of oil on plants. Oil Pollution Research Unit, Field studies Council. Environ. Pollut., 1:27-44.

Batterton, J.; Winters, K. and Van Ballen, C. (1978). Sensitivity of three microalgae to crude oils and fuel oils. Mar. Environ. Res., 1:31-41.

Ben-Amotz, A. and Avron, M. (1983). Accumulation of metabolites by halotolerant algae and its industrial potential. Ann. Rev. Microbiol., 37:95-119.

Bott, L; Kurt, R. and Philip, T. (1979). Effects of no. 2 fuel oil, Nigerian crude oil and crankcase oil on benthic algal communities. Environ. J. Sci., 13:751-779.

Boylan, D. B. and Tripp, B. W. (1971). Determination of hydrocarbons in seawater extracts of crude oil and oil fractions. Nature, 230(5288):44-47.

Chan, K. and Chiu, S. (1985). The effects of diesel oil and oil dispersants on growth, photosynthesis and respiration of Chlorella salina. Archs. Environ. Contam. Toxicol., 14:325-331.

Chapin, F. S. (1991). Integrated responses of plants to stress. Bioscience, 41:2936.

Chen, C.; Huang, J. and Wu, X. (1992). Effect of low concentration of fuel oils Nos 0 and 20 accommodated in intertidal water on growth of marine phytoplankton. Mar. Sci. Bull. Haiyang Tongbao, 11(2): 32-38.

Chitlaru, E. and Pick, U. (1989). Selection and characterization of Dunaliella salina mutants defective in haloadaptation. Plant Physiol., 91:788-794.

Coffey, J.; Ward, C. and King, J. (1977). Effects of petroleum hydrocarbons on growth of fresh-water algae. Devel. Indust. Microbiol., 18:661-672.

Cowan, A. K.; Rose, P. and Home, L. (1992). Dunaliella salina: A model system for studying the response of plant cell stress. J. Exper. Bot., 43(257):1535-1547.

Craigie, J. and McLachlan, J. (1964). Glycerol as a photosynthetic product of Dunaliella tertiolecta Batcher. Can. J. Bot., 42:777-778.

Czekanowski, J. (1913). Zarys metod statystycznych. Anthropol. Anz., 9:227249.

Davavin, S.; Mironov, O. and Tsimblal, I. (1975). Influence of oil on nucleic acids of algae. Mar. Pollut., 6:13-15.

Dennington, V; George, H. and Wyborn, C. (1975). The effect of oil on growth of fresh water phytoplankton. Environ. Pollut., 8:233-237.

Dubois, M.; Gilles, K. A.; Hamilton, J.K. and Smith, F. (1959). Phenolsulphoric acid colorimetric method for carbohydrate determination. In: Methods in carbohydrate chemistry. Whistler, L.R. and Wolform, R.L. (ed.) 388-403. Academic press New York.

Dunstan, W.M.; Atkinson, L.R. and Natoli, J. (1975). Stimulation and inhibition of phytoplankton growth by low molecular weight hydrocarbons. Mar. Biol., 31:305-310. 
El-Sheekh, M.; El-Naggar, A; Osman, M. and Haieder, A. (2000). Comparative studies on the green algae Chlorella homosphaera and Chlorella vulgaris with respect to oil pollution in the river Nile. Water, Air and Soil Pollution, 124:187-204.

Fabregas, J.; Herrero, C. and Veiga, M. (1984). Effect of oil and dispersant on growth and chlorophyll a content of the marine microalgae Tetraselmis suecica. Appl. Environ. Microbiol., 47(2): 445-447.

Gordon, D. and Prouse, N. (1973). The effect of three oils on growth and photosynthesis of micro-algae. Mar. Biol., 22:329-333.

Harrison, P.; Cochlan, W.; Acreman, J.; Parsons, T.; Thompson, P. and Dovey, H. (1986). The effect of crude oil and corexit 9527 on marine phytoplankton in an experimental enclosure. Mar. Envir. Res., 18:93-109.

Hegseth, E. and Ostgaard, K. (1985). Application of in-situ dialysis cultures in studies of phytotoxicity of North Sea crude oil. Water Res., 19:383-391.

Herman, D.; Inniss, W. and Mayfield, C. (1990). Impact of volatile aromatic hydrocarbons, alone and in combination, on growth of the fresh water alga Selenastrum capricorantum. Aquatic Toxicology, 18:87-100.

Hunfford, G. L. (1971). The biological response of oil in the marine environment, a review background report, Washington, DCUS, Coast Guard Oceanographic Unit, Office of Research and Development, US Coast Guard Headquarters.

Ikawa, M.; Mosley, S. and Barbero, L. (1992). Inhibitory effects of terpene alcohols and aldehydes on growth of green alga Chlorella pyrenoidosa. $J$. Chem. Ecol., 18(10):1755-1760.

Jaspers, E. M. (1965). Pigmentation of tobacco crown-gall tissues cultured in vitro independent of composition of medium. Physiol. Plant, 18:933-940.

Jankevicius, K.; Pakalnis, R.; Baranauskiene, A.; Jankevicius, L. and Jankeviciute, G. (1992). Effect of petroleum products pollution in the Baltic Sea upon the vital activity of planktonic organisms and the role of hydrocarbon as amater self-cleaning factor. Ekologija-EhkologiyaEcology, 4:39-52.

Jeffery, S. W. and Humphrey, G. F. (1975). New spectroscopic equation for determining chlorophyll $\mathrm{a}_{1}, \mathrm{~b}_{1}, \mathrm{c}_{1}$ and $\mathrm{c}_{2}$ in higher plants, algae and natural phytoplankton. Biochem. Physiol. Pflanzen., 167:191-194.

Jordan, T. N.; Uetlana, V. K.; Albena, P. I.; Kamen, L. S.; Stefco, D. D. K.; Stoitse, A. and Simeon, S. P. (2002). Effect of Diesel fuel pollution on the lipid composition of some wide-spread black sea algae and invertebrates. $Z$. Naturforsch., 57c:339-343.

Karydis, M. (1981). The toxicity of crude oil for the marine alga Scletonema costatum (Greville) in relation to nutrient limitation. Hydrobiol., 85:137143. 
Kauss, P. and Hutchinson, T. (1978). Effect of benzene, a water-soluble component of crude oils, on membrane integrity and ionic content of the green alga Ankistrodesmus falcalus. Water Pollut. Res., 13:20-31.

Kentzer, T. and Tukaj, Z. (1985). Growth responses of Scenedesmus quadricauda to oil pollution at different temperature and light intensities. Oceanologia, 22:41-49.

Krydis, M. (1979). Short term effects of hydrocarbons on photosynthesis and respiration of some phytoplankton species. Bot. Mar., 22:281-285.

Loeblich, L. A. (1982). Photosynthesis and pigments influenced by light intensity and salinity in the halophyte Dunaliella salina (Chlorophyta). J. Mar. Biol. Ass. UK., 62:493-508.

Lu, G. H.; Yuan, X. and Zhao, Y. H. (2001). QSAR study on the toxicity of substituted benzenes to the algae (Scenedesmus obliquus). Chemosphere, 44(3):437-440.

McKnight, M.; Pereira, E.; Rostad, E. and Stiles, A. (1983). Effect of retorated-oil shale leachate on blue-green alga Anabaena flos-aquae. Bull. Environ. Contam. Toxicol., 30:6-16.

Mohammady, N.; Chen, Y.; El_Mahdy, A. and Mohammad, R. (2005). Physiological response of the eustigmatophycean Nannochloropsis salina to aqueous diesel fuel pollution. Oceanologia., 47(1):75-92.

Nelson- Smith, A. (1970). The problem of oil pollution of the sea. Adv. Mar. Biol., 8:215- 306.

Newaey, S. and Seed, R. (1995). The effect of the Braer oil spill on rocky intertidal communities in South Shetland, Scotland. Marine Pollution Bulletin., 30(4):274-280.

Nunes, P. and Benville, P. (1979). Effect of water-soluble fraction of cook inlet crude oil on the marine alga Dunaliella tertiolecta. Bull. Environm. Contam. Toxicol., 21:727-732.

O'Brien, P. B. and Dixon, P. S. (1976). The effects of oils and oil components on algae. A review. Phycol. J., 11:115-142.

Piehler, M.; Swistak, J.; Pinckney, J. and Paerl, H. (1997). Sub-lethal effects of coastal petroleum pollution on Spartina alterniflora stem epiphytes. Chemosphere, 35(11):2665-2674.

Piehler, M.; Winkelmann, V.; Twomey, L.; Hall, N.; Currin, C and Paerl, H. (2003). Impact of diesel fuel exposure on the microphytobenthic community of an intertidal sand flat. J. Exp. Mar. Biol. Ecol., 297:219-237.

Scandalios, J. G. (1969). Genetic control of multiple molecular forms of enzymes in plants: A review. Biochem. Genet., 3:37-39.

Sheppard, C. and Price, A. (1991). Gulf war's oil slick: A threat to the ecosystem. Neys. Scientist., 129: 36-40.

Sikkema, J.; de Bont, J. and Poolman, B. (1995). Mechanisms of membrane toxicity of hydrocarbons. Microbiol. Rev., 59(2):201-222. 
Singh, A. K. and Gaur, J. P. (1990). Effect of petroleum oils and their parafinic aspaltic and aromatic fractions on photosynthesis and respiration of microalgae. Ecotoxicol. Environ. Saf., 19(1):8-16.

Tukaj, Z. (1987). The effect of crude and fuel oils on growth, chlorophyll a content and dry matter production of green alga Scenedesmus quadricauda. Environ. Pollut., 47:9-24.

Wang, y; Tang, X.; Li, Y. and Liu, Y. (2002). Stimulation effects of anthracene on marine microalgae growth. Sci. Total Environ., 13(3):343-346.

Wegman, K. (1969). On the pathway of $\mathrm{CO}_{2}$ fixation in Dunaliella. Progr. Photosynthetic Res., 3:1559-1564.

Wegman, K. (1971). Osmotic regulation of photosynthetic glycerol production in Dunaliella. Biochem. Biophys. Acta., 234:317-323.

Yang, S.; Wu, R. and Kong, R. (2002). Physiological and cytological responses of the marine diatom Scletonema costatum to 2, 4-dichlorophenol. Aquat. Toxicol., 60(1)-(2):33-41.

Zachleder, V. and Tukaj, Z. (1993). Effect of fuel oil and dispersant on cell cycle and macromolecular synthesis in the chlorococcal alga Scenedesmus armatus. Mar. Biol., 117:347-353.

Zawadzki, Z. and Langowska, I. (1982). Studies on the utilization of octane by algae. Plant Grunwaldzki., 9:350-377.

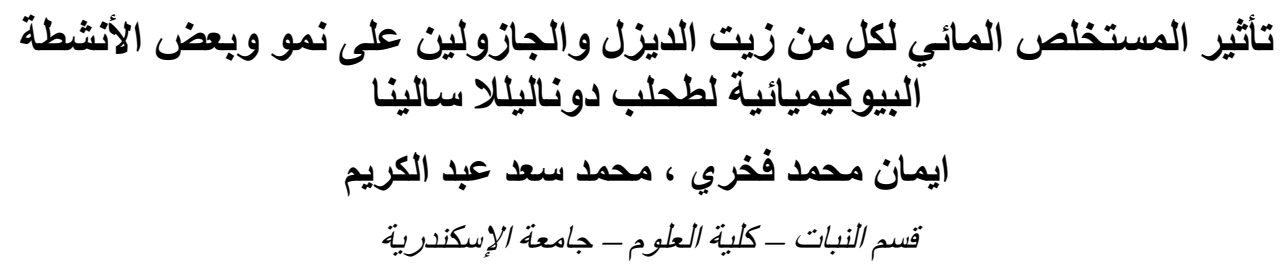

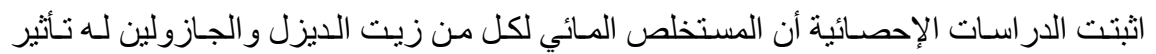

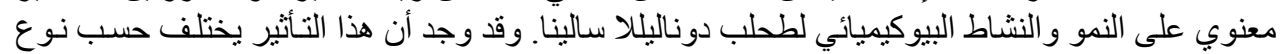

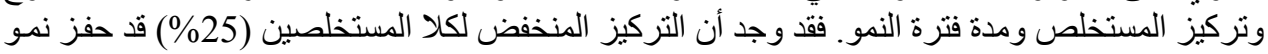

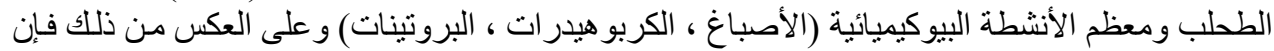

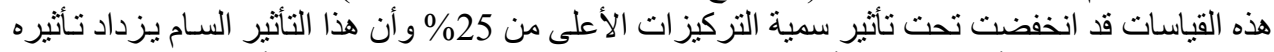

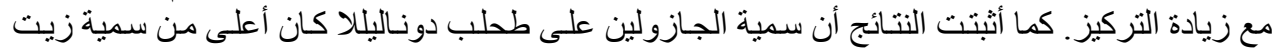

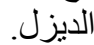

